\title{
GAYA BELAJAR MAHASISWA PENDIDIKAN MATEMATIKA UNIVERSITAS FLORES DALAM PEMAHAMAN KONSEP FUNGSI
}

\author{
Vivien Restianim ${ }^{1}$, Agnes Pendy $^{2}$, Juwita Merdja ${ }^{3}$ \\ Universitas Flores $1,2,3$ \\ agnespendy@gmail.com ${ }^{2}$
}

\begin{abstract}
The purpose of this research is to find out the dominant learning style of students of Department of Mathematic Education University of Flores in understanding the function concept and also to find out the correlation between gender and learning style. Furthermore, to determine the effect of learning styles on the learning outcomes of function materials. This type of research is qualitative and quantitative research. The results of this research is the majority of students of of Department of Mathematic Education University of Flores have Social group learning styles with 43.21\%. On the other hand, the majority of mathematics education students are women, but this does not affect the choice of learning styles. In this study, learning styles affect student learning outcomes on the understanding of the functions concept with an F count is 16.978 greater than $F$ table $=3.96$.
\end{abstract}

Keyword: Learning style, Function, Gender, Learning outcome

\begin{abstract}
Abstrak: Tujuan dalam penelitian ini yakni untuk mengetahui gaya belajar dominan mahasiswa program studi pendidikan matematika universitas flores dalam memahami konsep fungsi dan untuk mengetahui korelasi antara gender dengan gaya belajar. Lebih lanjut, untuk mengetahui pengaruh gaya belajar terhadap hasil belajar materi fungsi. Jenis penelitian yang digunakan adalah penelitian kualitatif dan kuantitatif. Hasil penelitian yang diperoleh yakni mayoritas mahasiswa Program studi Pendidikan Matematika Universitas Flores memiliki gaya belajar Social group dengan persentasi sebesar 43,21\%. Di lain pihak mayoritas mahasiswa pendidikan matematika berjenis kelamin perempuan namun hal tersebut tidak mempengaruhi pemilihan gaya belajar. Dalam penelitian ini, gaya belajar mempengaruhi hasil belajar siswa terhadap pemahaman konsep fungsi dengan $F$ hitung sebesar 16,978 lebih besar dari F tabel=3,96.
\end{abstract}

Kata Kunci: Gaya belajar; konsep fungsi;gender;hasil belajar

\section{PENDAHULUAN}

Konsep fungsi merupakan salah satu konsep dasar matematika yang wajib dipelajari oleh mathematician. Di Universitas Flores Program Studi Pendidikan Matematika, konsep fungsi muncul pada empat mata pelajaran keahlian yakni, matematika dasar, pengantar dasar matematika dan analisis real. Hal tersebut menunjukan betapa pentingnya penguasaan konsep fungsi bagi keberlanjutan penguasaan konsepkonsep matematika lainnya.

Dari hasil wawancara, dapat disimpulkan bahwa kesepuluh mahasiswa tersebut mampu memberikan definisi fungsi dengan lancar. Namun delapan dari sepuluh mahasiswa tidak mampu membedakan contoh pemetaan yang tergolong fungsi. Uniknya, jawaban sepuluh mahasiswa tersebut memiliki kesamaan, yakni berpedoman pada panca indra ataupun kemampuan diri untuk mengekspresikan ide atau keterampilan baru yang diciptakan. Hal tersebut menunjukan bahwa sepuluh mahasiswa tersebut mengandalkan gaya belajar yang dimiliki untuk memahami suatu konsep pembelajaran yang dipelajari. Dengan demikian, gaya belajar memiliki peranan penting dalam pemahaman suatu konsep pembelajaran dan setiap orang memiliki gaya belajarnya masing-masing yang belum tentu sama satu dengan yang lain. Ini diperkuat dengan pendapat yang 
dikemukakan oleh Nahlan M. Moussa dari Universitas Auburn di Montgomery, Alabama dalam Institute Of Learning Style Journal (2014), menyatakan bahwa "learning style have been shown to play an important role in the learning process. Each person has his/her own particular learning style that determines how he/she interacts with his/her learning environment".

Di Indonesia telah banyak penelitian untuk mengetahui gaya belajar siswa. Banyak penelitian memfokuskan pada tiga gaya belajar yakni visual, auditorial dan kinestetik. Seperti penelitian yang dilakukan oleh Bobbi De Poter \& Mike Hernacki (2005), dalam buku Quantum Learning: Membiasakan Belajar Nyaman dan Menyenangkan, menjelaskan secara umum gaya belajar manusia dibedakan dalam tiga kelompok besar yaitu gaya belajar visual, gaya belajar auditorial dan gaya belajar kinestetik. Gaya belajar visual adalah gaya belajar dengan cara melihat, mengamati, memandang dan sejenisnya. Kekuatan gaya belajar ini terletak pada indera penglihatan. Gaya belajar Auditorial adalah gaya belajar dengan cara mendengar. Individu dengan gaya belajar ini, lebih dominan dalam menggunakan indera pendengaran untuk melakukan aktivitas belajar. Sedangkan gaya belajar kinestetik adalah gaya belajar dengan cara bergerak, bekerja dan menyentuh.

Namun Fang Mei Tai dalam The Journal of Human Resource and Adult Learning (2013) menambahkan tiga gaya belajar yakni tactile learning style, Sociological Styles dan ComputerAssisted Style. Pertama, Tactile learning style merupakan gaya belajar yang memfokuskan pada sentuhan tangan. Salah satu ciri mahasiswa yang memiliki gaya belajar tactile adalah selalu menggaris bawahi bacaanya atau mencatat apa yang didengarkan. Kedua, gaya belajar sosiologis (Sociological
Style). Gaya belajar sosiologis terbagi menjadi dua yakni grup (kelompok) dan individu. Siswa dengan gaya belajar sosiologis grup mengutamakan interaksi dan kerja dalam kelompok. Dengan belajar dalam kelompok, siswa dengan gaya belajar ini lebih mampu memahami materi yang diajarkan. Sedangkan gaya belajar sosiologis individu lebih memilih untuk bekerja sendiri. Orang-orang dengan gaya belajar ini akan lebih cepat memahami konsep baru jika konsep tersebut dipelajari secara mandiri. Ketiga, gaya belajar dengan bantuan computer (Computer Assisted Style). Fang Mei Tai menyatakan bahwa dengan menggunakan gaya belajar ini pendidik mampu mencapai tujuan pembelajaran yang diinginkan.

Sehingga tujuan dalam penelitian ini yakni untuk mengetahui gaya belajar dominan mahasiswa program studi pendidikan matematika universitas flores dalam memahami konsep fungsi dan untuk mengetahui korelasi antara gender dengan gaya belajar. Lebih lanjut, tujuan lain dalam penelitian ini yakni untuk mengetahui pengaruh gaya belajar terhadap hasil belajar materi fungsi. Pada akhirnya, dengan mengetahui gaya belajar mahasiswa program studi pendidikan matematika universitas flores dalam pemahaman konsep fungsi dapat menjadi landasan bagi dosen pengampu mata kuliah pengantar dasar matematika dan matematika dasar untuk mengembangkan model pembelajaran berdasarkan gaya belajar.

\section{LANDASAN TEORI}

\section{Gaya Belajar (Learning Style)}

Setiap manusia yang lahir ke dunia ini selalu berbeda satu sama lainnya. Baik bentuk fisik, tingkah laku, sifat, maupun berbagai kebiasaan lainnya. Tidak ada manusia yang memiliki bentuk fisik, tingkah laku dan sifat yang sama walaupun kembar 
sekalipun. Suatu hal yang perlu diketahui bersama adalah bahwa setiap manusia memiliki cara menyerap dan mengolah informasi yang diterimanya dengan cara yang berbeda satu sama lainnya. Ini sangat tergantung pada gaya belajarnya. Menurut Fleming dan Mills (1992), gaya belajar merupakan kecenderungan siswa untuk mengadaptasi strategi tertentu dalam belajar sebagai bentuk tanggung jawabnya untuk mendapatkan satu pendekatan belajar yang sesuai dengan tuntutan belajar di kelas/sekolah maupun tuntutan dari mata pelajaran.

Rina Dunn dalam Deporter,dkk (2001), seorang pelopor di bidang gaya belajar, telah menemukan banyak variabel yang mempengaruhi cara belajar. Ini mencakup faktor-faktor fisik, emosional, sosiologis, dan lingkungan. Ada orang yang belajar paling baik secara berkelompok, sedang yang lain lagi memilih adanya figur otoriter seperti orang tua atau guru, yang lain merasa bahwa bekerja sendirilah yang paling efektif bagi mereka. Sebagian orang memerlukan musik sebagai latar belakang, sedang yang lain tidak dapat berkonsentrasi kecuali dalam ruangan sepi. Ada orang-orang yang memerlukan lingkungan kerja yang teratur dan rapi, tetapi yang lain lebih suka menggelar segala sesuatunya supaya semua dapat terlihat.

Menurut Bobbi De Poter \& Mike Hernacki (2005) secara umum gaya belajar manusia dibedakan ke dalam tiga kelompok besar, yaitu gaya belajar visual, gaya belajar auditorial dan gaya belajar kinestetik.

\section{Gaya Belajar Visual (Visual Learning Style)}

Gaya belajar visual adalah gaya belajar dengan cara melihat, mengamati, memandang, dan sejenisnya. Kekuatan gaya belajar ini terletak pada indera penglihatan. Bagi mahasiswa yang memiliki gaya ini, mata adalah alat yang paling peka untuk menangkap setiap gejala atau stimulus (rangsangan) belajar. Mahasiswa dengan gaya belajar visual senang mengikuti ilustrasi, membaca instruksi, mengamati gambargambar, meninjau kejadian secara langsung, dan sebagainya. Hal ini sangat berpengaruh terhadap pemilihan metode dan media belajar yang dominan mengaktifkan indera penglihatan (mata).Seorang yang bertipe visual, akan cepat mempelajari bahan-bahan yang disajikan secara tertulis, bagan, grafik, gambar.

Ciri-ciri menonjol dari mahasiswa yang memiliki tipe gaya belajar Visual yakni; 1) Senang kerapian dan ketrampilan; 2) Jika berbicara cenderung lebih cepat; 3) Ia suka membuat perencanaan yang matang untuk jangka panjang; 4) Sangat teliti sampai ke hal-hal yang detail sifatnya; 5) Mementingkan penampil-an, baik dalam berpakaian maupun presentasi; 6) Lebih mudah mengingat apa yang di lihat, dari pada yang di dengar; 7) Mengingat sesuatu dengan penggambaran (asosiasi) visual. ; 8) Ia tidak mudah terganggu dengan keributan saat belajar (bisa membaca dalam keadaan ribut sekali pun); 9) Ia adalah pembaca yang cepat dan tekun; 10) Lebih suka membaca sendiri dari pada dibacakan orang lain; 11) Tidak mudah yakin atau percaya terhadap setiap masalah atau proyek sebelum secara mental merasa pasti; 12) Suka mencoretcoret tanpa arti selama berbicara di telepon atau dalam rapat; 13) Lebih suka melakukan pertunjukan (demonstrasi) dari pada berpidato; 14) Lebih menyukai seni dari pada musik; 15) Sering kali mengetahui apa yang harus dikatakan, akan tetapi tidak pandai memilih katakata; 16) Kadang-kadang suka kehilangan konsentrasi ketika mereka ingin memperhatikan. Ciri-ciri bahasa tubuh yang menunjukkan seseorang 
gaya belajar Visual yaitu biasanya duduk tegak dan mengikuti penyaji dengan matanya.

\section{Gaya Belajar Auditorial}

Gaya belajar auditorial adalah gaya belajar dengan cara mendengar. Mahasiswa dengan gaya belajar ini, lebih dominan dalam menggunakan indera pendengaran untuk melakukan aktivitas belajar. Dengan kata lain, ia mudah belajar, mudah menangkap stimulus atau rangsangan apabila melalui alat indera pendengaran (telinga). Mahasiswa yang bertipe auditorial, mudah mempelajari bahanbahan yang disajikan dalam bentuk suara (ceramah), begitu dosen menerangkan ia cepat menangkap bahan pelajaran, disamping itu kata dari teman (diskusi) atau suara radio/video, ia mudah menangkap-nya. Mahasiswa dengan gaya belajar auditorial akan mengalami kesulitan memahami konsep dalam bentuk tulisan, perabaan, gerakangerakan yang ia mengalami kesulitan.

Indikator gaya belajar auditorial sebagai berikut. (1) Belajar dengan cara mendengar. Siswa yang bertipe auditori mengandalkan kesuksesan belajarnya melalui telinga/alat pendengarannya. Mereka belajar lebih cepat dengan menggunakan diskusi verbal dan mendengarkan apa yang guru katakan. (2) Baik dalam aktivitas lisan. Siswa auditorial berbicara dengan irama yang terpola, biasanya pembicara yang fasih, suka berdiskusi dan menjelaskan segala sesuatu panjang lebar (3) Memiliki kepekaan terhadap musik. Mereka mampu mengingat dengan baik apa yang didengar, sehingga dapat mengulangi kembali dan menirukan nada, birama, dan warna suara. (4) Mudah terganggu dengan keributan. Siswa dengan tipe auditorial ini peka terhadap suara yang didengarnya, jadi mereka akan sangat terganggu jika ada suara lain disamping dalam aktivitas belajarnya (5) Lemah dalam aktivitas visual. Informasi tertulis terkadang sulit diterima oleh siswa bergaya belajar auditori.

\section{Gaya Belajar Kinestetik}

Gaya belajar kinestetik adalah gaya belajar dengan cara bergerak, bekerja, dan menyentuh. Maksudnya ialah belajar dengan mengutamakan indera perasa dan gerakan-gerakan fisik. Orang dengan gaya belajar ini lebih mudah menangkap pelajaran apabila ia bergerak, meraba, atau mengambil tindakan. Misalnya, ia baru memahami makna halus apabila indera perasanya telah merasakan benda yang halus.

Indikator gaya belajar kinestetik sebagai berikut. (1) Belajar dengan aktivitas fisik. Siswa yang mempunyai gaya belajar kinestetik belajar melalui bergerak, menyentuh, dan melakukan. Mereka tidak tahan untuk duduk berlama-lama mendengarkan pelajaran dan merasa bisa belajar lebih baik jika prosesnya disertai kegiatan fisik. (2) Peka terhadap ekspresi dan bahasa tubuh siswa dengan gaya belajar kinestetik mudah menghafal dengan cara melihat gerakan tubuh/fisik sambil berjalan mempraktikkan. (3) Berorientasi pada fisik dan banyak bergerak siswa kinestetik biasanya mempunyai perkembangan awal otot-otot yang besar, menggunakan jari sebagai penunjuk ketika membaca, banyak menggunakan isyarat tubuh, suka praktik. (4) Suka coba-coba dan kurang rapi. Belajar melalui memanipulasi dan praktik, kemungkinan tulisannya jelek. (5) Lemah dalam aktivitas verbal. Cenderung berbicara dengan perlahan, sehingga perlu berdiri dekat ketika berbicara dengan orang lain.

Ketiga gaya belajar yang telah dikemukakan sebelumnya merupakan gaya belajar yang sering dipakai oleh para peneliti untuk meneliti gaya belajar peserta didik. Namun Fang Mei Tai dari National Penghu University of Science 
and Technology, Taiwan dalam The Journal of Human Resource and Adult Learning, Vol. 9 (2013) menambahkan tiga gaya belajar yaitu:

\section{Tactile Learning Style}

Tactile Learning style merupakan gaya belajar melalui sentuhan. Gaya belajar ini mengutamakan sentuhan tangan sebagai media dalam pembelajaran. Orang-orang yang memiliki gaya belajar ini senang melakukan percobaan/eksperimen. Siswa dengan gaya belajar ini senang menggaris bawahi buku bacaannya atau mencatat ketika mendengarkan. Dengan menulis membantu siswa mengingat informasi yang didengarkan. Siswa dengan gaya belajar ini juga senang memanipulasi suatu material.

\section{Sociological Styles/Gaya Belajar Sosiologis}

Gaya belajar sosiological terbagi atas dua yakni grup dan individu. Siswa dengan gaya belajar sosiological group mengutamakan interaksi dan kerja dalam kelompok. Dengan belajar dalam kelompok, siswa dengan gaya belajar ini lebih mampu memahami materi yang diajarkan. Sedangkan gaya belajar sosiological individua lebih memilih untuk bekerja sendiri. Orang-orang dengan gaya belajar ini akan lebih cepat memahami konsep baru jika konsep tersebut dipelajari secara mandiri.

\section{Computer-Assisted Style/gaya belajar dengan bantuan komputer}

Fang Mei Tai menyatakan bahwa dengan menggunakan gaya belajar ini pendidik mampu mencapai tujuan pembelajaran yang diinginkan. Hal tersebut dibuktikan dengan penelitian Hsu dalam Fang Mei Tai (2013) menemukan bahwa pendidik sebaiknya menggunakan teknologi komputer dalam membaca suatu kajian materi yang memiliki keragaman opini atau solusi.
Sebagai contoh, untuk mengatasi masalah kali item (kali sentiong) di Jakarta beberapa pakar memiliki solusi yang berbeda-beda. Pendidik bisa menjelaskan/mengkaji solusi-solusi tersebut dalam konteks bacaan dengan menggunakan teknologi webblog.

Namun dalam penelitian ini, peneliti menyadur dua dari tiga gaya belajar yang dikemukakan oleh Fang Mei Tai yaitu Social Style dan Computer-Assisted Style. Hal tersebut dikarenakan Tactile Learning Style memiliki karakteristik yang sebagian besar sama dengan Kinestetik.

\section{Pemahaman Konsep}

Arti pemahaman konsep dalam penelitian ini didasarkan pada Sanjaya (2009) yang menyatakan pemahaman konsep adalah kemampuan siswa yang berupa penguasaan sejumlah materi pelajaran, dimana siswa tidak sekedar mengetahui atau mengingat sejumlah konsep yang dipelajari, tetapi mampu mengungkapkan kembali dalam bentuk lain yang mudah dimengerti, memberikan interprestasi data dan mampu mengaplikasikan konsep yang sesuai dengan struktur kognitif yang dimilikinya.

Indikator pemahaman kosep menurut Shadiq (2009) adalah sebagai berikut:

1) Menyatakan ulang sebuah konsep, 2) Mengklasifikasi objek-objek menurut sifat-sifat tertentu (sesuai dengan konsepnya) , 3) Memberikan contoh dan non contoh dari konsep, 4) Memberikan konsep dalam berbagai bentuk representasi matematis , 5) Mengembangkan syarat perlu dan cukup suatu konsep, 6) Menggunakan, memanfaatkan, dan memilih prosedur atau operasi tertentu, 7) Mengaplikasikan konsep atau algoritma pemecahan masalah. 


\section{METODE PENELITIAN}

Jenis penelitian yang digunakan dalam penelitian ini adalah penelitian deskriptif dengan menggunakan pendekatan kualitatif dan penelitian kuantitatif. Penelitian deskriptif dengan pendekatan kualitatif digunakan untuk mengetahui gaya belajar dominan mahasiswa program studi pendidikan matematika Universitas Flores dalam pemahaman konsep fungsi. Sedangkan penelitian kuantitatif digunakan untuk mengetahui korelasi gender dengan gaya belajar dan untuk mengetahui seberapa besar pengaruh gaya belajar terhadap hasil belajar materi fungsi.

Subjek dalam penelitian ini sebanyak tiga puluh satu mahasiswa Program Studi Pendidikan Matematika yang terdiri dari mahasiswa semester empat dan mahasiswa semester enam.

Sedangkan Populasi dalam penelitian adalah mahasiswa Program Studi Pendidikan Matematika Universitas Flores. Sampel diambil sebanyak delapan puluh satu mahasiswa Program Studi Pendidikan Matematika Universitas Flores semester empat dan enam. Teknik pengambilan sampling dalam penelitian ini menggunakan teknik purposive sampling. Teknik ini dipilih karena penelitian difokuskan pada gaya belajar mahasiswa dalam pemahaman konsep fungsi. Sehingga diperlukan sampel dari mahasiswa yang telah mempelajari konsep fungsi. Dengan demikian mahasiswa semester empat dan semester enam memenuhi persyaratan dalam penelitian karena telah menempuh mata kuliah matematika dasar, pengantar dasar matematika dan Analisis Real.

Teknik pengumpulan data yang digunakan adalah angket, observasi dan tes dengan teknik analisis data yang digunakan untuk mengetahui gaya belajar mahasiswa Program Studi Pendidikan Matematika Universitas Flores, Langkah kedua yaitu penyajian data (data display) adalah tahap dimana data yang diperlukan dapat diolah sehingga dapat diperoleh gambaran secara umum apa yang telah diteliti. Tahap ketiga yaitu penarikan kesimpulan atau verifikasi (conclusion drawing/verification) adalah tahap dimana data yang telah dikumpulkan dapat ditarik kesimpulan tentang apa yang telah diteliti.

Untuk mengetahui korelasi antara gender dan gaya belajar, digunakan analisis Chi Square. Dalam menganalisis data, peneliti dibantu dengan program Statistical Package for the Social Sciences (SPSS).

Untuk mengetahui pengaruh gaya belajar terhadap hasil belajar, digunakan analisis regresi linear dengan hipotesis sebagai berikut:

Jika $F_{\text {hitung }}<F_{\text {tabel }}$ maka tidak ada pengaruh gaya belajar terhadap hasil belajar.

Jika $F_{\text {hitung }}>F_{\text {tabel }}$ maka ada pengaruh gaya belajar terhadap hasil belajar.

\section{HASIL PENELITIAN}

Hasil penelitian yang diperoleh yakni mayoritas mahasiswa Program studi Pendidikan Matematika Universitas Flores memiliki gaya belajar Social group dengan persentasi sebesar $43,21 \%$ dan gaya belajar visual dengan persentasi sebesar 33,33\% (dapat dilihat pada tabel 1). Namun uniknya pada item butir angket yang memuat pernyataan "saya suka mendengarkan penjelasan materi dari dosen" dimana merupakan indikator dari anak yang memiliki gaya belajar auditorial, seratus persen mahasiswa menjawab ya. Ini berarti walaupun mayoritas mahasiswa pendidikan matematika bergaya belajar Sociological Group dan visual, namun sumber utama informasi materi fungsi masih berpusat pada dosen. 
Sebaliknya pada item 12 dan 13 merupakan item dengan indikator gaya belajar visual yang sama yakni indikator "ketelitian sampai ke hal-hal yang sifatnya mendetail/ terperinci", menunjukan bahwa pada item 12, seratus persen siswa menjawab "tidak" yang berarti item tersebut bernilai 0 untuk gaya belajar visual. Sedangkan pada item 13, seratus persen siswa menjawab "ya", yang berarti bernilai 1 untuk gaya belajar visual. Dengan demikian dapat disimpulkan bahwa siswa mengerjakan solusi aljabar secara lebih mendetail dibandingkan mengerjakan solusi dengan menggunakan grafik.

Tabel 1. Distribusi Frekuensi Gaya Belajar

\begin{tabular}{lcc}
\hline \multicolumn{1}{c}{$\begin{array}{c}\text { Gaya } \\
\text { Belajar }\end{array}$} & Frekuensi & $\begin{array}{c}\text { Persentase } \\
(\%)\end{array}$ \\
\hline Visual & 35 & 33,33 \\
Auditorial & 2 & 2,47 \\
Kinestetik & 5 & 6,17 \\
Sociological & 5 & 6,17 \\
individual & & \\
$\begin{array}{l}\text { Sociological } \\
\text { Group }\end{array}$ & 27 & 43,21 \\
$\begin{array}{l}\text { Computer } \\
\text { assisted }\end{array}$ & 7 & 8,64 \\
\hline
\end{tabular}

Di lain pihak mayoritas mahasiswa pendidikan matematika berjenis kelamin perempuan namun hasil penelitian menunjukan bahwa gender mahasiswa tidak mempengaruhi pemilihan gaya belajar mahasiswa tersebut. Hal ini ditunjukan dengan nilai Asymp.Sig. $(2-$ sided) $>0,05$ (dapat dilihat pada tabel 2). Namun dalam penelitian ini, gaya belajar mempengaruhi hasil belajar siswa terhadap pemahaman konsep fungsi dengan $\mathrm{F}$ hitung sebesar 16,978 lebih besar dari $F$ tabel=3,96 (dapat dilihat pada tabel 3).
Tabel 2. Tabel Chi-Square tentang Korelasi antara Gender dan Gaya Belajar

\begin{tabular}{||l|r|r|r|}
\hline \multicolumn{4}{|c|}{ Chi-Square Tests } \\
\hline & \multicolumn{1}{|c|}{ Value } & \multicolumn{1}{c|}{ df } & $\begin{array}{c}\text { Asymp. Sig. } \\
\text { (2-sided) }\end{array}$ \\
\hline Pearson Chi-Square & $.559^{\mathrm{a}}$ & 5 & .990 \\
Likelihood Ratio & .784 & 5 & .978 \\
Linear-by-Linear & .207 & 1 & .649 \\
Association & & & \\
N of Valid Cases & 81 & & \\
\hline \multicolumn{1}{|c|}{ a.7 cells (58.3\%) have expected count less than 5. The } \\
minimum expected count is .23.
\end{tabular}

Tabel 3. Tabel ANOVA tentang Pengaruh Gaya Belajar Terhadap Hasil Belajar

\begin{tabular}{|c|c|c|c|c|}
\hline \multicolumn{5}{|c|}{$\mathrm{ANOVA}^{\mathrm{a}}$} \\
\hline & $\begin{array}{l}\text { Sum of } \\
\text { Squares }\end{array}$ & $\begin{array}{cc}\text { df } & \text { Mean } \\
& \text { Square }\end{array}$ & $\mathrm{F}$ & $\begin{array}{l}\text { Sig } \\
\text {. }\end{array}$ \\
\hline \multirow{3}{*}{$\begin{array}{l}\text { Regressio } \\
\mathrm{n} \\
\text { Residual } \\
\text { Total }\end{array}$} & 878.939 & 6146.489. & 16.97 & .00 \\
\hline & 638.482 & 8.628 & & \\
\hline & 1517421 & 80 & & \\
\hline \multicolumn{5}{|c|}{ a. Dependent Variable: HB } \\
\hline \multicolumn{5}{|c|}{ b. Predictors: (Constant), CAT, A, V, K, SG, SI } \\
\hline
\end{tabular}

Pada uji t (dapat dilihat pada tabel 4) yang menunjukan bahwa nilai sig gaya belajar visual, auditorial, kinestetik, sosial individu dan sosial grup kurang dari 0,05. Hal tersebut menunjukan kelima gaya belajar tersebut memiliki kontribusi terhadap hasil belajar. Dan nilai $t$ positif menunjukan variabel-variabel gaya belajar tersebut memiliki hubungan yang searah dengan hasil belajar. Berbeda dengan gaya belajar CAT (Computer-Assisted), nilai sig lebih besar dari 0,05 yang berarti gaya belajar Computer-Assisted tidak memberikan kontribusi yang signifikan terhadap hasil belajar. 
Tabel 4. Uji t tentang Pengaruh masing-masing Gaya Belajar Terhadap Hasil Belajar

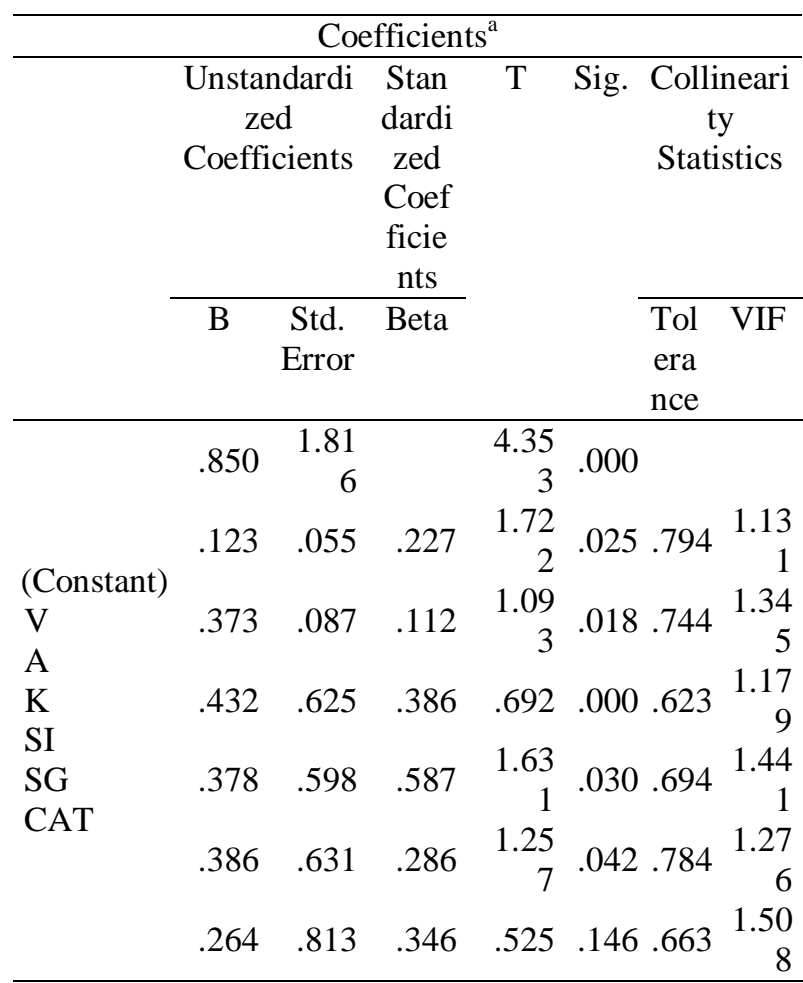

a. Dependent Variable: HB

\section{PEMBAHASAN}

Dari hasil wawancara, dapat disimpulkan bahwa kesepuluh mahasiswa tersebut mampu memberikan definisi fungsi dengan lancar. Namun delapan dari sepuluh mahasiswa tidak mampu membedakan contoh pemetaan yang tergolong fungsi. Uniknya, jawaban sepuluh mahasiswa tersebut memiliki kesamaan, yakni berpedoman pada panca indra ataupun kemampuan diri untuk mengekspresikan ide atau keterampilan baru yang diciptakan. Hal tersebut menunjukan bahwa sepuluh mahasiswa tersebut mengandalkan gaya belajar yang dimiliki untuk memahami suatu konsep pembelajaran yang dipelajari. Dengan demikian, gaya belajar memiliki peranan penting dalam pemahaman suatu konsep pembelajaran dan setiap orang memiliki gaya belajarnya masing-masing yang belum tentu sama satu dengan yang lain. Ini diperkuat dengan pendapat yang dikemukakan oleh Nahlan M. Moussa dari Universitas Auburn di Montgomery, Alabama dalam Institute Of Learning Style Journal (2014), menyatakan bahwa "learning style have been shown to play an important role in the learning process. Each person has his/her own particular learning style that determines how he/she interacts with his/her learning environment".

Rina Dunn dalam Deporter,dkk (2005), seorang pelopor di bidang gaya belajar, telah menemukan banyak variabel yang mempengaruhi cara belajar. Ini mencakup faktor-faktor fisik, emosional, sosiologis, dan lingkungan. Ada orang yang belajar paling baik secara berkelompok, sedang yang lain lagi memilih adanya figur otoriter seperti orang tua atau guru, yang lain merasa bahwa bekerja sendirilah yang paling efektif bagi mereka. Sebagian orang memerlukan musik sebagai latar belakang, sedang yang lain tidak dapat berkonsentrasi kecuali dalam ruangan sepi. Ada orangorang yang memerlukan lingkungan kerja yang teratur dan rapi, tetapi yang lain lebih suka menggelar segala sesuatunya supaya semua dapat terlihat.

Menurut Bobbi De Poter \& Mike Hernacki (2005) secara umum gaya belajar manusia dibedakan ke dalam tiga kelompok besar, yaitu gaya belajar visual, gaya belajar auditorial dan gaya belajar kinestetik.

\section{SIMPULAN}

Hasil penelitian yang diperoleh yakni mayoritas mahasiswa Program studi Pendidikan Matematika Universitas Flores memiliki gaya belajar Social group dengan persentasi sebesar $43,21 \%$. Di lain pihak mayoritas mahasiswa pendidikan matematika berjenis kelamin perempuan namun hal tersebut tidak mempengaruhi pemilihan gaya belajar. Dalam penelitian ini, gaya 
belajar mempengaruhi hasil belajar siswa terhadap pemahaman konsep fungsi dengan $\mathrm{F}$ hitung sebesar 16,978 lebih besar dari $\mathrm{F}$ tabel=3,96. Namun perlu diperhatikan bahwa hasil penelitian ini hanya berlaku untuk konsep fungsi, namun belum tentu sama dengan gaya belajar untuk materi keahlian matematika lainnya. Karena asumsinya, setiap orang kemungkian memiliki lebih dari satu gaya belajar.

\section{DAFTAR PUSTAKA}

Fleming, N. D. \& Mills, C. (1992). Helping Students Understand How They Learn. The Teaching Professor, 7(4)

Moussa, N. M. (2014). The Important of Learning Style in Education. Institute for Learning Style Journal. 1.19

Porter, B., \& Hernacki, M. (2001). Quantum Learning. Membiasakan Belajar Nyaman dan Menyenangkan. Kaifa: Bandung

Potter, B., \& Hernacki, M. (2005). Quantum Teaching. Bandung: Kaifa

Sanjaya, W. (2009). Strategi Pembelajaran Berorientasi Standar Proses Pendidikan. Jakarta: Kencana Prenada Media Group

Shadiq, F. (2009). Kemahiran Matematika. Yogyakarta: Departemen Pendidikan Nasional

Tai, F. M. (2013). Adult EFL Students' Learning Style and Motivation. The Journal of Human Resource and Adult Learning, 9 